Maciej Serowaniec

Uniwersytet Mikołaja Kopernika, Toruń

\title{
Wiedeński model kontroli spraw unijnych po wejściu w życie Traktatu z Lizbony - teoria i praktyka
}

DOI: http://dx.doi.org/10.12775/SIT.2015.027

Przystąpienie Austrii 1 stycznia 1995 roku do Unii Europejskiej pociągnęło za sobą istotne zmiany ustrojowe. W konsekwencji przekazania kompetencji organów władzy państwowej na szczebel ponadnarodowy doszło bowiem do „marginalizacji” znaczenia organów ustawodawczych, przy jednoczesnym wzmocnieniu roli organów władzy wykonawczej w krajowym systemie konstytucyjnym. Z tego właśnie względu istotną rolę w procesie włączania Austrii w struktury integracyjne odegrały kwestie odnoszące się do repartycji kompetencji pomiędzy organami państwa w zakresie decydowania o sprawach związanych z członkostwem we WE/ /UE. Jeszcze przed formalnym przystąpieniem Austrii do struktur integracyjnych w noweli konstytucyjnej z dnia 15 grudnia 1994 r. określone zostały konstytucyjnoprawne podstawy mechanizmu współpracy parlamentu $\mathrm{z}$ rządem w zakresie spraw związanych z członkostwem we Wspólnotach/Unii. Wprowadzony do Federalnej Ustawy Konstytucyjnej (Bundes-Verfassungsgesetz, dalej B-VG) nowy podrozdział B zatytułowany Unia Europejska (art. 23a-23f) ${ }^{1}$ stworzył szeroki mechanizm konsultacyjny między ciałami ustawo-

${ }^{1}$ Zob. 1013. Bundesverfassungsgesetz, mit dem das Bundes-Verfassungsgesetz in der Fassung von 1929 geändert wird sowie das EWRBundesverfas- 
dawczymi - Radą Narodową (Nationalrat) i Radą Federalną (Bundesrat) a rządem federalnym w sprawach dotyczących członkostwa w Unii Europejskiej². Tak skonstruowane ramy prawne zapewnić miały obu izbom austriackiego parlamentu realny wpływ na procesy podejmowania decyzji w sprawach związanych $z$ członkostwem we Wspólnotach/Unii. Włączenie Rady Federalnej w wewnątrzpaństwowe procesy decyzyjne dotyczące spraw integracyjnych miało również zagwarantować poszczególnym rządom krajów związkowych udział w prowadzonej przez rząd federalny polityce europejskiej ${ }^{3}$.

Cechą charakterystyczną wiedeńskiego modelu kontroli spraw integracyjnych jest relatywnie szeroki zasięg parlamentarnej kontroli europejskiej sfery aktywności rządu, której towarzyszy wzrost znaczenia wyspecjalizowanych komórek parlamentarnych. W parlamencie austriackim początkowo pojawiła się idea utworzenia silnego „Stałego Wspólnego Komitetu” (Ständiger Gemeinsamer Ausschuss)swoistej „Izby Europejskiej”, w skład której wchodziliby przedstawiciele Rady Narodowej, Rady Federalnej i austriaccy deputowani do Parlamentu Europejskiego. Ostatecznie, po niezwykle burzliwych dyskusjach politycznych, wykonywanie kompetencji Rady Narodowej w zakresie spraw związanych z członkostwem w UE zdecydowano się jednak powierzyć istniejącej Komisji Głównej (Hauptausschuss) ${ }^{4}$. Ze względu na swoje długie tradycje oraz doniosłą rolę w strukturach wewnętrznych określana jest często w literaturze mianem „rezerwowego parlamentu” ${ }^{5}$ Stosownie do postanowień art. 23k ust. 2

sungsgesetz und das EGKS-Abkommen-Durchführungsgesetz aufgehoben werden, BGBl. 1994/1013.

2 Por. szerzej J. Barcz, Parlament a Unia Europejska. Analiza prawna na przykładzie doświadczeń Austrii (wraz z podstawowymi dokumentami), Warszawa 1999, s. 29-35.

${ }^{3}$ Por. J. Osiński, Rola Parlamentów narodowych w sprawach Unii Europejskiej na przykładzie Austrii, Finlandii i Szwecji, w: Rola parlamentów narodowych $w$ perspektywie rozszerzenia UE oraz Konferencji Międzyrzadowej 2004, red. J. Barcz, S. Puzyna, Warszawa 2002, s. 183-187.

${ }^{4}$ Por. J. Barcz, Austria, w: Parlamenty a integracja europejska, red. M. Kruk, E. Popławska, Warszawa 2002, s. 123.

${ }_{5}$ Por. H. Widder, Rada Narodowa, w: Parlament Republiki Austrii, red. H. Schambeck, przeł. B. Banaszak, Warszawa 1997, s. 60-61. 
Konstytucji ${ }^{6 j e s t ~ o n a ~ w ~ s z c z e g o ́ l n o s ́ c i ~ o d p o w i e d z i a l n a ~ z a ~ z a j m o w a n i e ~}$ stanowisk i wyrażanie opinii na temat projektów aktów prawnych Unii Europejskiej oraz formułowanie zaleceń dla rządu dotyczących stanowisk prezentowanych na forum organów unijnych ${ }^{7}$. Regulacja konstytucyjna przesądziła zarazem o możliwości powołania w strukturze Komisji Głównej Stałej Podkomisji do spraw Unii Europejskiej (Ständiger Unterausschuss in Angelegenheiten der EU), której zakres powierzonych kompetencji winien być szczegółowo określony w regulaminie Rady Narodowej ${ }^{8}$.

Zgodnie $z$ postanowieniami art. 23k ust. 3 Konstytucji także austriacka Rada Federalna może powierzyć odpowiedniej komisji parlamentarnej wykonywanie określonych kompetencji Izby wynikających $z$ członkostwa w Unii Europejskiej ${ }^{9}$. W świetle postanowień $\S 13 a$ ust. 1 regulaminu Bundesratu ${ }^{10}$ rolę tego wyspecjalizowanego organu pełni Komisja do Spraw Unii Europejskiej (EU-Ausschuss), która odpowiedzialna jest za zajmowanie stanowisk i wyrażanie opinii na temat projektów aktów prawnych Unii Europejskiej oraz

${ }^{6} \mathrm{Na}$ podstawie art. 23k ust. 2 Federalnej Ustawy Konstytucyjnej wykonywanie kompetencji Rady Narodowej, o których mowa w art. 23e, 23f ust. 4, 23g, 23j ust. 2 Konstytucji powierza się jej Komisji Głównej. Zob. Federalna Ustawa Konstytucyjna Republiki Austrii z dnia 1 października 1920 r. ze zm., tłum. P. Czarny, B. Naleziński, w: Konstytucje państw Unii Europejskiej, red. W. Staśkiewicz, Warszawa 2011.

7 Por. O. Zehnpfund, A. Rhomberg, Parlamentarische Mitwirkung in Angelegenheiten der Europäischen Union in Dänemark, Frankreich, Österreich, Polen, Tschechien und im Vereinigten Königreich, Infobrief WD 11 - 3000 - 129/09, Deutscher Bundestag, s. 12-15.

${ }^{8}$ Zgodnie $z$ art. 23k ust. 2 Konstytucji Ustawa o regulaminie Rady Federalnej może przewidywać, że Komisja Główna wybiera Stałą Podkomisję, do której odpowiednio stosuje się postanowienia art. 55 ust. 3 Konstytucji i może przekazać tej Stałej Podkomisji wykonywanie kompetencji wynikających z członkostwa w Unii Europejskiej. Zob. także § 31 regulaminu Rady Narodowej.

${ }^{9}$ Zgodnie $\mathrm{z}$ art. 23k ust. 3 Konstytucji Kompetencje Rady Federalnej, o których mowa w art. 23e, 23f ust. 4 i 23 g mogą zostać zgodnie $z$ postanowieniami regulaminu Rady przekazane komisji wybieranej przez Radę.

${ }^{10}$ Zob. Geschäftsordnung des Bundesrates, BGBl. No 361/1988 idF [online], http://www.parlament.gv.at/PERK/RGES/GOBR/index.shtml [dostęp: 12 stycznia 2014 r.]. 
formułowanie zaleceń dla rządu dotyczących stanowisk prezentowanych na forum Rady ${ }^{11}$.

Po wejściu w życie Traktatu z Lizbony, na mocy noweli konstytucyjnej $z$ dnia 27 lipca 2010 roku $^{12}$, obie izby austriackiego parlamentu w sposób kompleksowy zostały także włączone w nowy obszar europejskiej działalności parlamentów związany z monitorowaniem przestrzegania zasady pomocniczości w ramach traktatowej procedury ex ante i ex post. Powierzono im także określone funkcje i zadania w zakresie wykonywania traktatowych uprawnień odnoszących się do akceptacji przedłożonych propozycji rewizji prawa pierwotnego, zarówno w ramach zwykłej, jak i uproszczonej procedury zmiany traktatów.

Mechanizmy przekazywania parlamentom narodowym informacji oraz dokumentów pochodzących od instytucji unijnych tradycyjnie warunkują aktywny udział parlamentów w inicjatywach podejmowanych na forum Unii Europejskiej. Zakres przekazywanych dokumentów pochodzących od instytucji unijnych z jednej strony zdeterminowany jest normami prawa traktatowego, $z$ drugiej zaś wynika $z$ przyjętego $w$ danym państwie członkowskim modelu współpracy rządu $z$ parlamentem $w$ sprawach europejskich ${ }^{13}$. Zgodnie z postanowieniami art. 23e B-VG właściwy członek rządu federalnego zobowiązany jest do niezwłocznego informowania Rady Narodowej i Bundesratu o wszystkich zamierzeniach związanych z członkostwem w Unii Europejskiej. Po wejściu w życie Traktatu

11 Por. H. Hegeland, Ch. Neuhold, Parliamentary participation in EU affairs in Austria, Finland and Sweden: Newcomers with different approaches, „European Integration online Papers" 10/2002, s. 3 [online], http://eiop.or.at/ eiop/texte/2002-010a.htm [dostęp: 6 maja 2015 r.].

12 Zob. 57. Bundesverfassungsgesetz, mit dem zur Durchführung des Vertrags von Lissabon das Bundes-Verfassungsgesetz und das Bundesverfassungsgesetz, mit dem besondere Bestimmungen für die Neuermittlung der Verteilung von nach der Wahl der Mitglieder des Europäischen Parlaments 2009 zu vergebenden Mandaten durch die Bundeswahlbehörde erlassen werden, geändert werden (Lissabon-Begleitnovelle), BGBl 2010/57.

${ }^{13}$ Por. A. Pudło, Rola drugich izb parlamentów państw członkowskich $w$ sprawach Unii Europejskiej $w$ świetle regulacji krajowych i unijnych, Warszawa 2011, s. 160. 
z Lizbony dotychczasowe przepisy konstytucyjne obligujące rząd do informowania parlamentu o sprawach związanych $\mathrm{z}$ członkostwem w UE uszczegółowione zostały na gruncie Ustawy federalnej o informacjach dotyczących Unii Europejskiej ${ }^{14}$, która weszła w życie dnia 1 stycznia 2012 roku $^{15}$. Z jej postanowień wynika, że obowiązek informacyjny dotyczy zarówno projektów aktów ustawodawczych UE, dokumentów konsultacyjnych Komisji Europejskiej (zielone księgi, białe księgi oraz komunikaty $\mathrm{KE}$ ), rocznych programów prac legislacyjnych, jak też wszelkich innych dokumentów odnoszących się do planowania legislacyjnego lub strategii politycznej Komisji Europejskiej. Ponadto obie izby austriackiego parlamentu otrzymują porządki obrad i wyniki posiedzeń Rady UE, w tym protokoły posiedzeń Rady rozpatrującej projekty aktów ustawodawczych. Rozszerzona procedura informacyjna dotyczy również inicjatyw Rady Europejskiej związanych z przyjęciem decyzji o rewizji traktatów w tzw. procedurze kładki, przewidzianej w art. 48 ust. 7 akapit pierwszy lub drugi TUE. Zgodnie $z$ postanowieniami Traktatu $z$ Lizbony parlamenty narodowe informowane są o tych inicjatywach co najmniej sześć miesięcy przed przyjęciem jakiejkolwiek decyzji. Rada Narodowa oraz Bundesrat otrzymują ponadto informacje na temat wniosków o przystąpienie do Unii, zgodnie $z$ art. 49 TUE. Regulaminy parlamentarne zgodnie wskazują przy tym na Komisję Główną i jej Stałą Podkomisję do spraw UE oraz Komisję do Spraw Unii Europejskiej, jako organy właściwe do rozpatrywania projektów aktów ustawodawczych UE oraz pozostałych dokumentów odnoszących się procesu integracyjnego.

O specyfice austriackich rozwiązań przesądza jednak przede wszystkim ustanowiony, na gruncie regulacji konstytucyjnej, mechanizm konstruktywnej kooperacji w zakresie formułowania sta-

${ }^{14}$ Zob. Bundesgesetz über Information in EU-Angelegenheiten (EU-Informationsgesetz - EU-InfoG) [online], http://www.parlament.gv.at/PERK/RGES/ EU-InfoG/EU-Info.shtml\#P1 [dostęp: 23 kwietnia 2014 r.].

15 Por. Annex to the 17th biannual report of COSAC: National Parliaments' replies to the questionnaire, Prepared by the COSAC Secretariat and presented to: ol XLVII Conference of Community and European Affairs Committees of Parliaments of the European Union 22-24 April 2012 Kopenhaga, s. 2-6. 
nowisk odnośnie „wszystkich przedsięwzięć w ramach UE”. Komisje do spraw europejskich austriackiej Rady Narodowej i Bundesratu uzyskały bowiem uprawnienia do formułowania, w imieniu danej Izby, stanowisk odnośnie przedsięwzięć podejmowanych w ramach Unii Europejskiej. W tym przypadku opinia danej komisji winna stanowić podstawę stanowiska rządu w toku negocjacji oraz głosowania na forum UE. Należy jednak zwrócić uwagę, że może być ona naruszona przez rząd w sytuacji, gdy istnieją ważne powody z zakresu polityki integracyjnej. $\mathrm{W}$ takim przypadku członek rządu musi każdorazowo wyjaśnić przyczyny niezastosowania na forum UE określonego przez komisje stanowiska.

Komisja Główna może sformułować, w imieniu Rady Narodowej, stanowiska o charakterze względnie wiążącym w odniesieniu do podjętych w ramach Unii Europejskiej przedsięwzięć, które polegają na wydaniu wiążącego aktu prawnego, mającego skutki w postaci wydania ustawy federalnej w dziedzinie uregulowanej w tym akcie. Zgodnie z postanowieniami austriackiej Federalnej Ustawy Konstytucyjnej właściwy minister federalny związany jest w toku negocjacji i głosowania w Unii Europejskiej stanowiskiem Rady Narodowej i może od niego odstąpić jedynie $z$ ważnych względów dotyczących polityki zagranicznej i integracyjnej (art. 23e ust. 3) ${ }^{16}$. Jak podkreśla się w literaturze, pojęcie „ważnych względów dotyczących polityki zagranicznej i integracyjnej” odnosi się do zaistnienia okoliczności niezbędnych dla realizacji ważnych interesów Austrii w Unii Europejskiej ${ }^{17}$. Przyjęcie takiej konstrukcji w praktyce zapewnia rządowi federalnemu znaczną swobodę działania. Natomiast w odniesieniu do podjętych w ramach Unii Europejskiej przedsięwzięć, wymagających wydania federalnych przepisów rangi konstytucyjnej albo zawierałyby regulacje, które tylko w taki sposób mogłyby być podjęte, opinia Komisji Głównej ma charakter kwalifikowanego stanowiska wiążącego. Odstąpienie od takiego stanowiska jest dopuszczalne tylko wówczas, jeśli Rada Narodowa (w praktyce Komisja Główna) w stosownym terminie się mu nie sprzeciwi. W przypadku,

${ }^{16}$ Por. M. Mayer, Die Europafunktion der nationalen Parlamente in der Europäischen Union, Tübingen 2012, s. 380.

17 Por. J. Barcz, Parlament a Unia Europejska, s. 30. 
gdy właściwy minister federalny zamierza odstąpić od stanowiska Rady Narodowej, regulacja konstytucyjna przewiduje specyficzny mechanizm konsultacyjny w odniesieniu do analizowanych kategorii stanowisk. Po pierwsze właściwy minister federalny powinien w stosownym momencie zgłosić zamiar odstąpienia od stanowiska Komisji Głównej, ponownie przedkładając daną sprawę Radzie Narodowej. Po drugie zaś po głosowaniu w Radzie Europejskiej winien on przedstawić Radzie Narodowej (de facto Komisji Głównej lub Stałej Podkomisji ds. UE) sprawozdanie i powiadomić ją w danym przypadku o powodach, dla których odstąpił od stanowiska Izby. Ponadto Komisja Główna zwykłą większością głosów może podjąć decyzję o skierowaniu inicjatywy dotyczącej członkostwa w Unii Europejskiej na posiedzenie plenarne Rady Narodowej w celu jej rozpatrzenia na forum Izby ${ }^{18}$.

Komisja do Spraw UE austriackiej Rady Federalnej może $z$ kolei formułować wobec rządu kwalifikowane stanowiska o charakterze wiążącym, o ile realizacja przedsięwzięcia w ramach UE wymaga wydania przepisów federalnych rangi konstytucyjnej ograniczających właściwość krajów w ustawodawstwie lub wykonawstwie, które zgodnie $z$ art. 44 ust. 2 Konstytucji, wymagają zgody Rady Federalnej. Także w odniesieniu do wiążących aktów prawnych UE, zawierających regulacje, dzięki którym takie przepisy mogłyby zostać wydane, stanowisko Komisji ma charakter kwalifikowany. W obu tych przypadkach właściwy minister federalny związany jest bowiem w toku negocjacji i głosowania w Unii Europejskiej stanowiskiem Rady Federalnej oraz może od niego odstąpić jedynie $z$ ważnych względów dotyczących polityki zagranicznej, a także integracyjnej. Odstąpienie takie jest w każdym razie dopuszczalne tylko wówczas, gdy Rada Federalna w stosownym terminie mu się nie sprzeciwi. Ponadto właściwy minister federalny winien po głosowaniu w Radzie Europejskiej przedstawić Radzie Federalnej sprawozdanie i powiadomić ją w danym przypadku o powodach, dla których

18 Por. B. Blümel, Ch. Neuhold, The Parliament of Austria: A „normative” Tiger?, w: National Parliaments and European Democracy. A Bottom-up Approach to European Constitutionalism, red. O. Tans, C. Zoethout, J. Peters, Groningen 2007, s. 146-151. 
odstąpił od stanowiska Rady. Ustanowiona, na gruncie art. 23e ust. 4 Konstytucji, kwalifikowana procedura opiniodawcza wynika zatem $z$ federalnego charakteru państwa i służy przede wszystkim wzmocnieniu roli rządów związkowych w prowadzonej przez rząd federalny polityce unijnej ${ }^{19}$.

W odniesieniu do pozostałych przedsięwzięć podjętych w ramach Unii Europejskiej zarówno Komisja Główna, jak i Komisja Spraw Unii Europejskiej mogą sformułować pod adresem właściwego ministra federalnego stanowiska o charakterze niewiążącym (art. 23e ust. 1 Konstytucji).

Jak podkreśla Jan Barcz, ustanowiony mechanizm współudziału Izby Narodowej i Rady Federalnej w procesach decyzyjnych dotyczących spraw unijnych nadaje obu izbom daleko idące uprawnienia, z drugiej zaś strony „wymusza” konstruktywną kooperację pomiędzy parlamentem a rządem w sprawach integracyjnych ${ }^{20}$. W praktyce komisje do spraw europejskich austriackiego parlamentu stosunkowo rzadko decydują się jednak na opracowanie mandatu o charakterze wiążącym. $Z$ reguły wydają one bowiem rekomendacje, które pozwalają ministrom na bardziej elastyczną politykę w trakcie prowadzonych negocjacji na forum organów unijnych ${ }^{21}$.

Przyznanie parlamentom narodowym roli „strażnika zasady pomocniczości” niosło za sobą konieczność ustanowienia na gruncie prawa krajowego wewnętrznych procedur określających formę oraz tryb uchwalania uzasadnionych opinii. W przypadku parlamentu austriackiego uprawnienia w zakresie monitorowania zgodności z zasadą pomocniczości unijnych aktów ustawodawczych określone zostały na gruncie regulacji konstytucyjnej (art. 23g). Stosownie do postanowień art. 23g ust. 1 austriackiej Konstytucji w związku z § 13a ust. 2 pkt 5 regulaminu Rady Federalnej, uzasadnione opinie w imieniu Izby formułuje Komisja do Spraw Europejskich. Warto przy tym zwrócić uwagę, że - za pośrednictwem Bundesratu $-z$ prawa podnoszenia zarzutu naruszenia przez projekt aktu

19 Por. M. Mayer, op. cit., s. 404-406.

20 Por. szerzej J. Barcz, Parlament a Unia Europejska, s. 29-35.

${ }^{21}$ Por. J. Marszałek-Kawa, Pozycja ustrojowa i funkcje Sejmu Rzeczypospolitej Polskiej po akcesji do Unii Europejskiej, Warszawa 2012, s. 72. 
ustawodawczego UE zasady pomocniczości korzystać mogą również izby parlamentów krajowych (Landtage). Natomiast Rada Narodowa wykonywanie kompetencji związanych $\mathrm{z}$ monitorowaniem zgodności unijnych aktów ustawodawczych z zasadą pomocniczości powierzyła Komisji Głównej i jej Stałej Podkomisji do Spraw Unii Europejskiej, która może przedłożyć wniosek zawierający uzasadnioną opinięę2.

Od momentu wejścia w życie Traktatu $z$ Lizbony Rada Narodowa zainicjowała postępowanie o stwierdzenie niezgodności unijnego aktu ustawodawczego wobec dwóch projektów przedłożonych jej do oceny, natomiast Rada Federalna zgłosiła do tej pory zastrzeżenia wobec aż dwunastu projektów unijnych aktów ustawodawczych ${ }^{23}$. Należy przy tym dostrzec, że większość uzasadnionych opinii formułowanych przez austriacki Bundesrat koncentrowała się na wnioskach ustawodawczych $z$ dziedziny opodatkowania, rolnictwa, rynku wewnętrznego oraz sprawiedliwości, a więc kwestiach szczególnie newralgicznych $\mathrm{z}$ punktu widzenia partykularnych interesów poszczególnych państw członkowskich. Jednym $z$ podstawowych zarzutów podnoszonych przez obie izby austriackiego parlamentu był brak wystarczających przesłanek merytorycznych pozwalających stwierdzić, że Unia Europejska jest faktycznie lepiej predestynowana do uregulowania danego zagadnienia niż państwa członkowskie. W ocenie Bundesratu jednym z zasadniczych problemów pojawiających się $w$ toku przeprowadzanej oceny zgodności $z$ zasadą pomocniczości projektów aktów ustawodawczych UE jest również zbyt szeroki zakres przepisów kompetencyjnych upoważniających Komisję Europejską do przyjmowania aktów delegowanych oraz wydawania aktów wykonawczych zawartych w poddawanych ocenie wnioskach legislacyjnych ${ }^{24}$.

22 Por. Mitwirkung in EU-Angelegenheiten [online], http://www.parlament.gv.at/PERK/PE/MIT/EUMitAllgemeines/index.shtml [dostęp: 12 maja 2015 r.].

${ }^{23}$ Por. Wykaz uzasadnionych opinii przyjętych przez Radę Narodową i Bundesrat zamieszczony na stronie internetowej Komisji Europejskiej: http:// ec.europa.eu/dgs/secretariat_general/relations/relations_other/npo/austria/ /2010_en.htm [dostęp: 4 maja 2015 r.].

${ }^{24}$ Por. szerzej Sprawozdania roczne Komisji Europejskiej w sprawie pomocniczości i proporcjonalności za lata 2010-2014, dostępne na stronie interne- 
Traktat $z$ Lizbony przyznał także parlamentom narodowym czynną legitymację procesową w zakresie przedkładania do Trybunału Sprawiedliwości UE skargi w sprawie naruszenia przez unijny akt ustawodawczy zasady pomocniczości. Szczegółowe procedury określające formę oraz tryb wykonywania przez obie izby austriackiego parlamentu kontroli ex post wynikają z postanowień art. 23h Federalnej Ustawy Konstytucyjnej. Przedłożenie przez Radę Narodową lub Bundesrat skargi do Trybunału Sprawiedliwości UE, stwierdzającej niezgodność unijnego aktu ustawodawczego z zasadą pomocniczości następuje w drodze uchwały podjętej bezwzględną większością głosów w obecności co najmniej 1/3 członków Izby. Inicjatywa uchwałodawcza w tym zakresie przysługuje każdemu parlamentarzyście, przy czym inicjatywa taka musi uzyskać poparcie przynajmniej czterech członków danej Izby. Na forum komisji parlamentarnych odpowiedzialnych za sprawy europejskie następuje natomiast proces przetwarzania inicjatyw parlamentarnych, w wyniku którego zapadają kierunkowe rozstrzygnięcia dla późniejszych decyzji podejmowanych przez parlament na posiedzeniu plenarnym.

Ważny element budujący poczucie „odpowiedzialności integracyjnej” austriackiego parlamentu za dynamiczny rozwój Unii Europejskiej stanowi także kwalifikowany mechanizm współpracy rządu $z$ parlamentem w zakresie rozpatrywania i zatwierdzania propozycji przedłożonych w ramach tzw. procedury kładki. Zgodnie $z$ postanowieniami art. 23i B-VG ustrojodawca przewidział bowiem wymóg uprzedniego uzyskania akceptacji parlamentu dla stanowisk zajmowanych przez rząd federalny w ramach procedury kładki. W przypadku tzw. procedury kładki sensu stricto (art. 48 ust. 7 TUE), która polega na „przejściu” z głosowania jednomyślnego na rzecz większości kwalifikowanej w Radzie lub zmianie specjalnej procedury prawodawczej na zwykłą, stanowisko rządu federalnego wymaga uzyskania uprzedniego upoważnienia Rady Narodowej,

towej Centrum Informacji i Dokumentacji Europejskiej: http://oide.sejm.gov. pl/oide/index.php?option=com_content\&view=article\&id=14857\&Itemid=990 [dostęp: 9 maja 2015 r.]. 
udzielonego za zgodą Bundesratu. Warto przy tym podkreślić, że analogicznie, jak w przypadku procedury dokonywania zmian Federalnej Ustawy Konstytucyjnej, tak również w przypadku akceptacji propozycji przedłożonej w ramach procedury kładki obie Izby wyrażają swoje stanowisko większością kwalifikowaną 2/3 głosów w obecności co najmniej połowy ustawowej liczby członków ${ }^{25}$.

Przyznanie parlamentom narodowym uprawnień w zakresie wniesienia sprzeciwu wobec inicjatywy Rady, zmierzającej do zmiany prawa pierwotnego w ramach procedury kładki sensu stricto, niosło za sobą konieczność ustanowienia na gruncie prawa krajowego stosownych procedur określających formę oraz tryb wykonywania traktatowych uprawnień parlamentów. W świetle postanowień art. 23 i ust. 2 B-VG wyrażenie sprzeciwu wobec przedłożonej propozycji zmiany traktatu $\mathrm{w}$ ramach procedury kładki sensu stricto wymaga uchwały przez parlament działający in gremio. Zarówno Rada Narodowa, jak i Rada Federalna podejmuje stosowną uchwałę bezwzględną większością głosów w obecności co najmniej $1 / 3$ członków danej Izby.

Federalna Ustawa Konstytucyjna przesądza, że uprzedniej akceptacji Rady Narodowej i Bundesratu wymagają także stanowiska rządu federalnego odnoszące się do decyzji Rady UE, wprowadzających nowe kategorie zasobów własnych Unii Europejskiej (art. 311 TfUE). W przypadku obu izb stosowna zgoda wyrażana jest w formie uchwały podjętej większością kwalifikowaną 2/3 głosów, przy obecności co najmniej połowy ustawowej liczby członków Izby. W przypadku pozostałych decyzji Rady UE, odnoszących się do spraw związanych z systemem zasobów własnych UE ustrojodawca przewidział wymóg uzyskania uprzedniej zgody Rady Narodowej, która przybiera postać uchwały podjętej bezwzględną większością głosów w obecności co najmniej 1/3 członków Izby. W odniesieniu do pozostałych form prawotwórczej aktywności Rady Europejskiej i Rady UE, które wymagają następczego zatwierdzenia przez pań-

25 Por. Sz. Pawłowski, Zmiany Konstytucji Austrii jako wyraz jej europeizacji, w: Europeizacja konstytucji państw Unii Europejskiej, red. K. Kubuj, J. Wawrzyniak, Warszawa 2011, s. 49-50. 
stwa członkowskie zgodnie $z$ odpowiednimi wymogami konstytucyjnymi, zastosowanie będą miały postanowienia art. 50 ust. 4 B-VG. Ich akceptacja będzie zatem pociągała za sobą konieczność uzyskania uprzedniej zgody Rady Narodowej i Bundesratu, wyrażonej większością kwalifikowaną 2/3 głosów przy obecności co najmniej połowy ustawowej liczby członków Izby.

W kontekście wzmocnienia demokratycznej legitymacji instytucji unijnych ważnym aspektem działalności parlamentów narodowych jest ich udział w procedurach wyłaniania kandydatów na niektóre stanowiska w instytucjach UE. Ogólne wytyczne dotyczące procedury opiniowania przez austriacką Radę Narodową kandydatów na niektóre stanowiska w instytucjach unijnych określone zostały na gruncie Federalnej Ustawy Konstytucyjnej (art. 23c). Zgodnie z obowiązującą regulacją przed formalnym wystawieniem kandydatur na stanowiska członka Komisji Europejskiej, sędziego Trybunału Sprawiedliwości UE i Trybunału Obrachunkowego, jak też członka Rady Administracyjnej Europejskiego Banku Inwestycyjnego, rząd federalny zobowiązany jest zawiadomić o zamiarze przedłożenia danej kandydatury Radę Narodową oraz Prezydenta. Ostateczne propozycje rządu federalnego odnośnie nominowanych kandydatów winny zostać złożone w porozumieniu z Komisją Główną Rady Narodowej (art. 23c Konstytucji). Stosownie do postanowień § 29 ust. 2 lit. a regulaminu Rady Narodowej, przed nominacją danego kandydata, rząd federalny zobowiązany jest „osiągnąć porozumienie” z Komisją Główną. Opinia Komisji Głównej powinna zatem stanowić podstawę stanowiska rządu w tym przedmiocie. W świetle obowiązujących regulacji jej opinie nie mają jednak charakteru bezwzględnie wiążącego, stanowią one bowiem jedynie wyraz woli politycznej komisji, jako organu działającego w imieniu danej Izby.

Wiedeński model kontroli gwarantuje zatem Radzie Narodowej i Radzie Federalnej aktywny udział w wewnątrzpaństwowych procesach decyzyjnych dotyczących spraw integracyjnych. Jego istotą jest stworzenie ram prawnych dla kooperatywnego współdziałania parlamentu i rządu w sprawach związanych z członkostwem w Unii Europejskiej, które starają się godzić interesy narodowe $z$ wymogami integracyjnymi. Wiedeński system kontroli spraw unijnych stał się również wzorcem dla rozwiązań ustrojowych przyjętych 
m.in. w chorwackim Saborze, słowackiej Radzie Narodowej oraz węgierskim Zgromadzeniu Narodowym ${ }^{26}$.

\section{STRESZCZENIE}

Wiedeński model kontroli spraw unijnych po wejściu w życie Traktatu z Lizbony - teoria i praktyka

Jeszcze przed formalnym przystąpieniem Austrii do struktur integracyjnych w noweli konstytucyjnej z dnia 15 grudnia 1994 r. określone zostały konstytucyjnoprawne podstawy mechanizmu współpracy parlamentu $\mathrm{z}$ rządem w zakresie spraw związanych z członkostwem we Wspólnotach/Unii. Wprowadzony do Federalnej Ustawy Konstytucyjnej nowy podrozdział B zatytułowany Unia Europejska (art. 23a-23f) stworzył szeroki mechanizm konsultacyjny między ciałami ustawodawczymi - Radą Narodową i Radą Federalną a rządem federalnym w sprawach dotyczących członkostwa w Unii Europejskiej. Wiedeński model kontroli spraw unijnych gwarantuje obu izbom parlamentu aktywny udział w wewnątrzpaństwowych procesach decyzyjnych dotyczących spraw integracyjnych. Kooperatywne współdziałanie parlamentu i rządu w sprawach związanych $\mathrm{z}$ członkostwem w Unii Europejskiej stara się bowiem godzić interesy narodowe $z$ wymogami integracyjnymi. Wiedeński system kontroli spraw unijnych stał się wzorcem dla rozwiązań ustrojowych przyjętych m.in. w chorwackim Saborze, słowackiej Radzie Narodowej oraz węgierskim Zgromadzeniu Narodowym.

Słowa kluczowe: wiedeński model kontroli spraw unijnych; Rada Narodowa; Rada Federalna; Bundesrat; Austria; rola parlamentów narodowych w Unii Europejskiej; kontrola parlamentarna procesów integracyjnych

${ }^{26}$ Por. A. Buzogány, Potemkin'sche Parlamente? Die Europagremien mittelosteuropäischer Staaten zwischen Schein und Sein, w: Parlamentarische Kontrolle und Europäische Union, red. B. Eberbach-Born, S. Kropp, A. Stuchlik, W. Zeh, Baden-Baden 2013, s. 405-406. 


\section{SUMMARY}

The cooperation of the council of ministers with the national parliaments in matters relating to membership of the European union - the Austrian model of EU scrutiny

Each national parliament of the EU-28 has put in place scrutiny procedures to reinforce democratic control over EU matters and to ensure democratic accountability in EU decision making. One widespread type of Austrian scrutiny is the "mandating system". As the name indicates, systems where the focus in on the process of EU decision-making rather than on an individual document emanating from the EU institutions belong to this scrutiny model. The principal subject of scrutiny is often the national government's position in the Council. The procedural system includes in some cases a power for a European Affairs Committee to give a direct mandate to a government before a minister can endorse legislation in Council meetings. Such systems are today in place in countries such as Croatia, Slovakia and Hungary.

Keywords: EU scrutiny procedures; National Council; Federal Council; Bundesrat; European Affairs Committee; Austrian parliament and EU; mandating system; EU decision making

\section{BIBLIOGRAFIA}

Barcz J., Parlament a Unia Europejska. Analiza prawna na przyktadzie doświadczeń Austrii (wraz z podstawowymi dokumentami), Warszawa 1999.

Barcz J., Austria, w: Parlamenty a integracja europejska, red. M. Kruk, E. Popławska, Warszawa 2002.

Blümel B., Neuhold Ch., The Parliament of Austria: A „normative” Tiger?, w: National Parliaments and European Democracy. A Bottom-up Approach to European Constitutionalism, red. O. Tans, C. Zoethout, J. Peters, Groningen 2007.

Buzogány A., Potemkin'sche Parlamente? Die Europagremien mittelosteuropäischer Staaten zwischen Schein und Sein, w: Parlamentarische Kontrolle und Europäische Union, red. B. Eberbach-Born, S. Kropp, A. Stuchlik, W. Zeh, Baden-Baden 2013.

Marszałek-Kawa J., Pozycja ustrojowa i funkcje Sejmu Rzeczypospolitej Polskiej po akcesji do Unii Europejskiej, Warszawa 2012. 
Mayer M., Die Europafunktion der nationalen Parlamente in der Europäischen Union, Tübingen 2012.

Osiński J., Rola Parlamentów narodowych w sprawach Unii Europejskiej na przykładzie Austrii, Finlandii i Szwecji, w: Rola parlamentów narodowych $w$ perspektywie rozszerzenia UE oraz Konferencji Międzyrzadowej 2004, red. J. Barcz, S. Puzyna, Warszawa 2002.

Pawłowski Sz., Zmiany Konstytucji Austrii jako wyraz jej europeizacji, w: Europeizacja konstytucji państw Unii Europejskiej, red. K. Kubuj, J. Wawrzyniak, Warszawa 2011.

Pudło A., Rola drugich izb parlamentów państw członkowskich $w$ sprawach Unii Europejskiej $w$ świetle regulacji krajowych $i$ unijnych, Warszawa 2011.

Widder H., Rada Narodowa, w: Parlament Republiki Austrii, red. H. Schambeck, przeł. B. Banaszak, Warszawa 1997.

Zehnpfund O., Rhomberg A., Parlamentarische Mitwirkung in Angelegenheiten der Europäischen Union in Dänemark, Frankreich, Österreich, Polen, Tschechien und im Vereinigten Königreich, Infobrief WD 11 - 3000 129/09. 
